\title{
Lies, Bullshit and Fake News
}

\author{
Alison MacKenzie ${ }^{1} \cdot$ Ibrar Bhatt $^{1}$ \\ Published online: 26 October 2019 \\ (C) Springer Nature Switzerland AG 2019
}

\section{Lies, Bullshit and Fake News: a Consideration of Their Epistemic Vices}

Virtue epistemology is a branch of philosophy that is concerned with the intellectual and character qualities a person requires in order to inquire about the state of knowledge. Intellectual virtues include being open-minded, intellectually courageous, curious and free from dogmatism and having humility. These cognitive character traits can be thought of as regulating inquiry and deliberation. The virtuous enquirer seeks truth and truthfulness to establish, as far as possible, the best descriptive and analytical account of a given state of affairs. This enquirer is one who is not afraid to ask hard questions such as the following: what are the harms to the British economy of leaving the European Union? How do intemperate, impetuous and uninformed tweets undermine US' foreign policy? (And we can insert an example from almost any country, anywhere, but these are the contexts we know best.) The virtuous enquirer will adopt methods of inquiry that should allow her to obtain answers that truthfully, honestly and accurately represent what is happening in reality. ${ }^{1}$

Epistemic virtues are beneficial qualities from which all can gain: they increase the flow of knowledge on which we can rely and trust to make informed judgements; all that is, except the (vainglorious) liar since these are the very qualities that can thwart his intention to deceive. Epistemic vices, such as lying, harm us as knowers because they impede our attempts to acquire knowledge (Cassam 2019) by presenting us with defective propositions about knowledge. Epistemic vices include, 'close mindedness, arrogance, dogmatism, prejudice, over-confidence, and wishful thinking' (Cassam 2019) — and contempt for, or indifference to, truth. These vices carry a moral charge

\footnotetext{
${ }^{1}$ There is a challenge to the idealism of this argument. We are assuming that epistemologists are not blind to the racial assumptions that construct their epistemological frameworks. See, example, Collins (2004), the collected essays on race and ignorance in Sullivan and Tuana (2007), and Medina (2013).

Alison MacKenzie

A.Mackenzie@qub.ac.uk

Ibrar Bhatt

i.bhatt@qub.ac.uk
}

1 Queen's University, Belfast, UK 
in that they are not only blameworthy, they are reprehensible: they are failings for which the person can be criticised and (often) held accountable ${ }^{2}$. If virtues can, broadly, be understood as excellences, vices are defects of character that result in bad ends or effects, and usually entail bad motives.

Since the 2016 referendum on the UK's membership of the European Union (the socalled Brexit vote), and the election of Donald Trump in the USA, research into epistemic vices has surged creating a branch of philosophy known as 'vice epistemology', or the 'philosophical study of the nature, identity and significance of epistemic vices' (Cassam 2019). Cassam (2019) also suggests that epistemic vices are key to understanding recent political developments. The political lives of many countries have been filled with lies, dogmatism, closed-mindedness, cultivated and willed ignorance (Bhatt and MacKenzie 2019), wilful belief and so on: they fill the air we breathe or the platforms we use. On Cassam's analysis, the political conduct of many politicians can be explained by their epistemic vices, as well as by the need for (ruthless) political strategies to maintain their core supporters.

Take wishful thinking. This can be regarded as an epistemic vice because the person so engaged wants a reality that conforms to his wishes - what he wants to be truerather than one which is founded on evidence. The assertions, rhetoric or propaganda that emerges from wishful thinking (and indeed, wilful belief), the sheer audacity of it even, is a common feature of the times in which we presently live. One example is the claim that we should just 'get Brexit done' ${ }^{3}$ and then, Prime Minister Boris Johnson and his supporters claim, we can reunite the country. The claim, naturally, belies the sheer complexity of disentangling the UK from a 40-year relationship with the EU, and how deeply, perhaps dangerously, divided the country is about the referendum and the consequent Brexit process.

We have also witnessed remarkable epistemic arrogance on the part of many of our politicians who wilfully defy or subvert constitutional conventions. Epistemic arrogance is an unwillingness to learn from others, a refusal to be open-minded, and to wilfully believe what one wants to believe. What characterizes the epistemically arrogant is their conviction that they know the truth, how things are, and are often passionate in their conviction that something is or is not true. So convinced are they that their conviction can verge on dogmatism - an irrational commitment to a set of beliefs, resulting in a distorted relationship with the truth. Like all the vices discussed here, epistemic arrogance describes a complex social-psychological set of attitudes (Lynch 2018). To pick out some of the features of the vice, Lynch describes four 'characters': the Obnoxious Uncle who listens to no-one and dismisses alternative viewpoints; the Dogmatic Listener who listens politely, responds to the points being made, but never changes her mind: she does actively listen but is waiting only for her turn to speak. She fails 'to be open-minded' (284); the Mainsplainer who is capable of listening and learning but who improperly takes the credit for what another has pointed out to him;

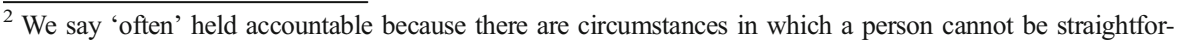
wardly blamed for his dogmatism or prejudice, for example. A person brought up in a community which firmly believes that homosexuality is sinful may not be culpable. However, this does not mean that the person cannot change the way she or he thinks.

${ }^{3}$ At the time of writing how the UK will exit the EU is far from clear. The slogan for the Conservative party 2019 was 'get Brexit done'. Negotiations with Europe will be ongoing for at least another ten years.
} 
and finally the Gaslighter who unfairly attributes blame to another for his defects. Lynch gives the example of a politician who is deeply racially biased which

often leads him to make mistaken and harmful judgments about particular people and policies. Called out on these judgments, he strongly denies he is biased, even when he acknowledges mistakes that are clearly a result of that bias. Instead, he blames others for 'racializing' the issue. (Lynch 2018: 285)

Assuming that he can admit to these faults, the Gaslighter may know he is wrong or that he is biased; the fault for these defects lie elsewhere. Through persistent denial, lying, contradiction or misdirection, the Gaslighter aims to sow doubt in, or about, targeted individuals or groups in order to undermine confidence and trust in their own or others' beliefs. A now daily and ubiquitous example is that the media is 'fake news' and 'corrupt', a defensive (and relentless) deflection from fault or expose. The arrogance displayed in these examples is based on self-delusion about why their world view is correct: it is correct because it is a view that 'reflects their self-esteem' (Lynch 2018: 286).

The epistemically arrogant are also over-confident about what they know. They act on their policies because they know their beliefs to be both true and correct, simply in virtue of their being his (Lynch 2018: 286). They also have a tendency to falsely, perhaps negligently, think they are doing good. ${ }^{4}$ This does not mean, Lynch argues, that they are enduringly committed to their belief but if there is a shift in belief, reality will surely shift with it. However, 'Committing to such a view, in the manner of selfdeception generally, is irrational, and doubly so, since it means not only embracing an absurd view of truth, but embracing it unstably - since people are rarely stable or uniform in their arrogance'. (Lynch 2018: 287)

The arrogant do not care about truth, according to Lynch. That is because the truth or correctness of their world view rests on some unassailable feature of their person and position: they are powerful, or belong to the right class, gender, religion, political party or country (Lynch 2018: 287). Arrogant people may not be arrogant with everyone, or their arrogance may vary in intensity, depending on with whom the arrogant person is interacting: the scope for arrogance, in other words, may vary widely. A person or group may be arrogant because they are in the governing party where truth is not the issue, party loyalty is; or they may be respectful and humilitous to another on account of their status (as President, Prime Minister or great artist). Presented with a group for whom the person has contempt or no regard (the media, let's say), then epistemic arrogance will come to the fore.

Indifference to, or contempt for, the truth is also an epistemic vice. Why enquire after the truth if one does not care for it or if it is not necessary? Bullshit will suffice. The bullshitter's aim is not to describe reality correctly; he is 'faking things' and is a

\footnotetext{
${ }^{4}$ MAGA (Make America Great Again), President Trump's 2016 election slogan, may be an example of this. No doubt, President Trump's believers ardently believe, like the President himself, that America is being made great, though on what grounds is far from evident. Holding migrant children separated from their parents in cages along the Mexican-US border should be judged as a vicious act of inhumanity. The revelry with which the President mocks or disdains people of colour, the disabled, migrants, countries and their leaders, and the evidence advanced to justify his revelry and their denigration, debases epistemic wellbeing, and is opposed to knowledge creation.
} 
'phony' and what he says has no connection to the truth (Frankfurt 2006). On the other hand, if the intention of the deceiver is to wilfully deceive, concern for, and sensitivity to the truth may be necessary but only in order to pervert it for a plausible, truthful sounding alternative. The strategy is to achieve credulity and support for the desired outcome through cynical and manipulative means.

As should be apparent, epistemic vices can present significant barriers to engaging in honest discussion, deliberation on matters of national or institutional importance, and participation in processes which have a bearing on who governs or leads, or disseminates information. Vicious motivations and their effects undermine trust, encourage tolerance of cavalier attitudes to trust, pander to self-esteem and ego, result in loss of trust in institutions, experts, and democratic processes. These constitute bad epistemic effects.

\section{Genesis of This Special Issue on Lies, Bullshit and Fake News}

There have been increasing concerns that fake news in online platforms is undermining the legitimacy of the press, the democratic process, and the authority of sources such as science, the social sciences and qualified experts. Google, YouTube, Twitter, Facebook, and other platforms have global reach and are being used to spread fake and misleading news quickly and seemingly without control. Until recently, these platforms have also been very unwilling to interfere with and remove offensive and dishonest material. In addition to their power and reach, these platforms operate, and indeed thrive, in what seems to be an increasingly balkanised media eco-system where networks of users will predominantly access and consume information that conforms to their existing worldviews, remaining within their epistemic bubbles, confined to echo chambers, in which conflicting positions, even if relevant and authoritative, are suppressed, discredited or overlooked - or simply kept out.

Should we be concerned? Have epistemic vices spread or been strategically manufactured through exploiting our information ecosystem? It is tempting to think that with the intense reporting on lies, bullshit and fake news, publics everywhere are facing a crisis of honesty and trust through calculated onslaughts on these values. The dissemination of false or misleading news, negative campaigns about disfavoured people or groups, and lies, scams and bullshit, is hardly new; these are epistemic practices which have an ancient pedigree. Nevertheless, is there something that marks out our times as having surpassed the vicious practices of deliberate misinformation in other periods? In the 1990s, many of us embraced the Internet for its democratising and civic potential, so how did we get to where we are now?

Most people now use online platforms, including social media feeds, as their main source of news, views, and evidence. One particular role that the Internet, particularly social media, has played in the spread of lies, bullshit and fake news is that it has resulted in amplification. Perpetrators of lies, bullshit and fake news have achieved this by exploiting the information ecosystem we are currently in through the networked infrastructure of a platform and the likelihood that algorithms will prioritise content that is clickable. The spread of anti-vaccination ideas is a case in point. For example, YouTube has a plethora of scientific videos about the value of vaccinations, but various types of 'anti-vaccine' videos (including recordings of emotional parents) have also 
flooded YouTube with the latter, often labelled as 'pro-safe vaccines' (see Hussain et al. 2018). This has resulted in platforms linking the two forms of content together as ostensibly two valid and equal sides of opinion. Notably, this has caused multiple measles outbreaks in Western countries where the measles virus had been eradicated.

Avoiding lies, bullshit and fake news, the theme of this special issue, seems impossible. In our call for abstracts we asked contributors to consider what the difference between a lie, bullshit and a fake news story is; whether it is defensible to lie, bullshit or spread fake stories; how online users distinguish the fake from the real, the truthful from the dishonest, and an authority from a propagandist. The papers gathered in this collection (and see below) aim to answer these questions.

\section{Creating a Constructive Epistemic Community}

Knowing that getting published can be a slow, sometimes brutal and discouraging process, we were keen to ensure that new and established writers would have a positive experience in engaging with the journal and this special issue. We therefore took it as our mission to mentor new writers through the process of writing and publication. We were also keen that accepted authors agree to review one paper from the collection, our assumption - and stipulation - being that they would be critically and constructively sympathetic to the aims of the writer. This special issue contains contributions from authors who have yet to embark on a $\mathrm{PhD}$, who are writing or have just recently completed one, as well as contributions from established academics.

The special issue also presents a cross-disciplinary mix of scholarly contributions each of which advances important insights into the theme. The variety and diversity of approaches to the problems highlighted in the call are also apparent when reading through the individual articles of this special issue, as briefly outlined below.

\section{The Collection in Brief}

The special issue opens with two commentaries on the nature of truth. In our introductory commentary we (MacKenzie and Bhatt 2019a) explore the difference between a lie, bullshit and fake news, and whether it is ever defensible to lie or bullshit. We argue that some lies are defensible, even necessary, but that lying should not be promoted as a moral good. Lying can destroy trust, and trust acts as the foundation of relations among human beings. The continual assertion of falsehoods and the sheer volume of information on digital environments make it very difficult to know what can be trusted. One consequence of all these lies is the unfair distribution of power wherein power rests with the liar, while the deceived are excommunicated from the realm of truth.

Suzanne Soohoo (2019) laments the current situation in the USA in which truth, and what we can count as true, has become endangered, sunk in a 'swamp of falsehoods'. So extensive are the lies that lying has become normal and ignorance legitimised. Anything that contradicts the fantasies is scornfully dismissed as 'fake'. The consequence of 'truth decay' is 'paralysis, alienation and disengagement'. In a not dissimilar argument to MacKenzie and Bhatt above, truth is a 'common good' the defence for 
which we need to immunise ourselves to resist and challenge the malign effects of lies and ignorance.

Oliver (2019) draws from infrastructure studies, an area of Science and Technology Studies, to explore the relationship between social media and political rhetoric. Oliver's analysis forces us to question technologically deterministic accounts of technology's relationship with society. Twitter, as a platform with a certain set of infrastructural logics, is implicated in the rise of post-truth rhetoric, in that it both creates new norms for discourse and enables new forms of inequality to operate.

Carr et al. (2019) present a case study on Spanish immigration and how fake news, disinformation and misinformation have been used to limit or eliminate the 'other'. Rumours, fear, stereotypes and prejudice have been deployed to persuade, deceive and manipulate people by very strongly appealing to their emotions. As there is no easy way to cope with the 'hydra' that is the digital world, digital literacy needs to be addressed through intersectoral work: the State, NGOs, civil society, education and citizens.

Sinclair (2019) uses parody to explore fake news. Parody, like fake news, is imitative, but while fake news aims to deceive, parody does not; it aims to provoke laughter and to expose and ridicule, and can be a necessary weapon in countering fake news. The primary aim of lies, bullshit and fake news, in contrast to the jests, jokes and exposees of parody, is to deceive and to deflect from what is true.

Jiang and Vetter (2019) examine bots in Wikipedia, and consider implications for cultivating students' critical media literacy. They argue that information validation processes through bots in Wikipedia are entangled across a series of human and nonhuman relations and agencies. Despite the platform's claim that these bots are for combating misinformation, their efficacy is challenged by the emergence of misogyny, systemic bias, and conflicts of interest. Studying the function of Wikipedia bots, therefore, makes space for developing models for critical media literacy in education.

Özdan (2019) explores the art of diplomacy and how Trump's diplomacy and foreign relations by tweet are imperilling this art and the country's international standing. A diplomat, he argues, should give the right judgement, have a steady mind, have an evenness of temper and be courteous, civil and polite. Unfortunately, Özdan argues, bullshit is the only 'art' inherent in the foreign policy engagements that Trump exercises by tweet with dangerous consequences.

Wright (2019) offers a philosophical analysis of how naïve scepticism, a willingness to endorse unsupported scepticism, and how it predisposes us to 'bullshit openness'. We accept bullshit because it conforms to deeply held convictions, because it expresses what group members should believe, or because we are intellectually lazy. The answer to bullshit is not to fight it on social media - it is too diverse, too fast, too limiting, and fosters incivility; we need collaborative strategies in which meanings are not imposed on students but are co-constructed.

Focusing on the Yes Men, Kedar (2019) uses tactical media, an activist-artistic approach that developed in the museum, to show how hoaxes, like parody, exposes lies, bullshit and fake news. Tactical media is also subversive but it focuses on the doing of the act, not the talking, to move us from critique to mobilisation, and the Yes Men are examples of this kind of subversion. Tactical media is an act of temporary deception that seeks to create belief in an event only to reveal the truth behind it. Kedar gives a sophisticated analysis of the differences between the fake of Trumps tweets, and the fake of the Yes Men's stunts. 
Wagener (2019) does not directly explore lies, bullshit and fake news. Instead, he focuses on how online communications and interactions trigger the production of fake news, bullshit and lies. Wagener suggests that we are in an era of hypernarrativity, or storytelling, in which what matters is not the truth of the story, but whether the story is a 'good' one, and use the rise of the gilet jaunes movement in France. Like MacKenzie and Bhatt (2019b), he explores how truth has become relativized in a bid to tell the good story.

Khan (2019) argues for an approach that draws a link between trust, which is crucial to democracy, and media and information literacy (MIL). She outlines how, through the negotiability of greater trust, MIL, and democratizing principles, civic agency might be advanced by educating a citizenry to be more literate about media and information systems, to generate democratic institutional change.

Lydia Rose and Teresa Bartoli (2019) speak of the 'intellectual darkness' that has descended on the USA, where contention seems to be more important than facts. Using the framework of agnotology, they examine how culturally induced ignorance has resulted in a rise in fear and xenophobia, distrust in evidence, and how covert actions undermine the evidence of, for example, climate change and the efficacy of vaccinations.

Jennifer Rose (2019) attends to what it means to be a diligent knower and how online news consumers can acquire knowledge. She argues that the epistemological magnitude of online fake news is a barrier to knowledge acquisition and democratic decision making. Jennifer Rose, like Wright, argues that combatting online fake news is not a simple matter-fact checking alone will not help. The measures Rose proposes to combat the susceptibility to consume fake news are the development of virtues such as intellectual humility, for example. These will take time to develop but are necessary if we are to acquire knowledge we can trust.

We end the special issue with a discussion on truth and trust (MacKenzie and Bhatt $2019 b$ ). Truth, we argue, must be respected and safeguarded because it is important to the integrity of the person, institution and nation. If we are indifferent to truth, or engage in practices which distort or fake the truth, then we undermine trust. Critiquing the arguments for the relativity of truth, we explore the means by which truth can be established, in addition to the differences between lies and bullshit, and how we can come to know and trust that something is true.

In their various ways, then, these articles expose the dangers of lies, truth and fake news, and acknowledge that combatting these vices will not be easy. At best, we must be vigilant and questioning, and literate about how lies insinuate their way into our belief systems.

\section{References}

Bhatt, I., \& Mackenzie, A. (2019). Just Google it! Digital literacy and the epistemology of ignorance. Teaching in Higher Education, 24(3), 302-317. https://doi.org/10.1080/13562517.2018.1547276.

Carr, P. R., Cuervo Sanchez, S. L., \& Daros, M. A. (2019). Citizen engagement in the contemporary era of fake news: hegemonic distraction or control of the social media context? Postdigital Science and Education. https://doi.org/10.1007/s42438-019-00052-z .

Cassam, Q. (2019). Cynicism, epistemic insouciance and Boris Johnson. Philosophers' Magazine, September. https://www.philosophersmag.com/essays/206-intellectual-vices. Accessed 10 Oct 2019. 
Collins, P. H. (2004). Black sexual politics. African Americans, gender and the new racism. New York: Routledge.

Frankfurt, H. G. (2006). On Truth. New York: Alfred A. Knopf.

Hussain, A., Ali, S., Ahmed, M., \& Hussain, S. (2018). The anti-vaccination movement: a regression in modern medicine. Cureus, 10(7), e2919. https://doi.org/10.7759/cureus.2919.

Jiang, J., \& Vetter, M. A. (2019). The good, the bot, and the ugly: problematic information and critical media literacy in the postdigital era. Postdigital Science and Education. https://doi.org/10.1007/s42438-01900069-4

Khan, S. (2019). Negotiating (dis)Trust to Advance Democracy through Media and Information Literacy. Postdigital Science and Education. https://doi.org/10.1007/s42438-019-00072-9.

Kedar, H. E. (2019). Fake news in media art: fake news as a media art practice vs. fake news in politics. Postdigital Science and Education. https://doi.org/10.1007/s42438-019-00053-y.

Lynch, M. P. (2018). Arrogance, truth and public discourse. Episteme, 15(3), 283-296. https://doi.org/10.1017 /epi.2018.23.

Mackenzie, A., \& Bhatt, I. (2019a). Lies, bullshit and fake news: some epistemological concerns. Postdigital Science and Education. https://doi.org/10.1007/s42438-018-0025-4.

Mackenzie, A., \& Bhatt, I. (2019b). Opposing the power of lies, bullshit and fake news: the value of truth. Postdigital Science and Education.

Medina, J. (2013). The epistemology of resistance: gender and racial oppression, epistemic injustice, and the social imagination. Oxford: Oxford University Press.

Oliver, M. (2019). Infrastructure and the post-truth era: is Trump Twitter's fault? Postdigital Science and Education. https://doi.org/10.1007/s42438-019-00073-8 .

Özdan, S. (2019). Subverting the art of diplomacy: bullshit, lies and Trump. Postdigital Science and Education. https://doi.org/10.1007/s42438-019-00075-6 .

Rose, J. (2019). To believe or not to believe: an epistemic exploration of fake news, truth, and the limits of knowing. Postdigital Science and Education. https://doi.org/10.1007/s42438-019-00068-5 .

Rose, L., \& Bartoli, T. (2019). Agnotology and the epistemology of ignorance: a framework for the propagation of ignorance as a consequence of technology in a Balkanized media ecosystem. Postdigital Science and Education.

Sinclair, C. (2019). Parody: fake news, regeneration and education. Postdigital Science and Education. https://doi.org/10.1007/s42438-019-00054-x .

Soohoo, S. (2019). Truth seeking. Postdigital Science and Education. https://doi.org/10.1007/s42438-01900047-w .

Sullivan, S., \& Tuana, S. (2007). Race and the epistemology of ignorance. New York: SUNY.

Wagener, A. (2019). Hypernarrativity, storytelling, and the relativity of truth: digital semiotics of communication and interaction. Postdigital Science and Education. https://doi.org/10.1007/s42438-019-00066-7 .

Wright, J. (2019). Many people are saying...': applying the lessons of naïve skepticism to the fight against fake news and other 'total bullshit'. Postdigital Science and Education. https://doi.org/10.1007/s42438019-00051-0. 